\title{
Large Cell/Anaplastic Medulloblastoma
}

National Cancer Institute

\section{Source}

National Cancer Institute. Large Cell/Anaplastic Medulloblastoma. NCI Thesaurus. Code C129436.

A medulloblastoma composed of sheets of large cells mixed with cells characterized by marked nuclear pleomorphism and hig h mitotic activity. 